Egyptian Poultry Science Journal

http://www.epsaegypt.com

ISSN: 1110-5623 (Print) - 2090-0570 (On line)

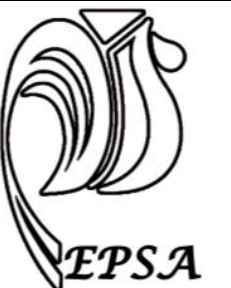

\title{
EFFECT OF DIETARY ARGININE SUPPLEMENTATION ON SOME HORMONES AND ITS RELATION TO PERFORMANCE OF SILVER MONTAZAH CHICKEN.
}

\section{2- THE EFFECT ON LAYING DURATION.}

\section{M. Sabry**, A. E. El-Slamony*, M. M. Soliman*, A. A. El-Zaiat* and Hanan S. Mohamed*}

Dep. of Poult. Breeding Res.* Dep. of Poult. Nutr. Res**

Anim. Prod. Res. Insti., Agric. Res. Center, Dokki, Giza, Egypt.

Received: 26/ 01/2016 Accepted: 26/02/2016

ABSTRACT: This experiment was conducted in Inshas Poultry Research Station, Ministry of Agricultural, Egypt, A total number of 420 hens and 105 cocks from Silver Montazah chickens (SM) (Egyptian local strain) flock were used to investigate the effect of dietary supplemental of arginine (Arg) levels on plasma nitric oxide (NO) and Insulinlike growth factor (IGF-I), testosterone (Testo) and luteinizing (LH) hormones concentrations, and their relation to productive and reproductive performance during laying period (28-40 wks of age). Birds were randomly divided into 7 experimental groups (each of 3 replicates). Each replicates consisted of 20 hens and 5 cocks. The $1^{\text {st }}$ group (T1) was fed the basal diet and served as the control group with no additional Arg $(15,12.5$ and $12.8 \mathrm{~g} \mathrm{Ar} / \mathrm{kg}$ diet $)$ for the starter, grower and finisher diet, respectively. The $2^{\text {nd }}, 3^{\text {rd }}$ and $4^{\text {th }}$ groups were fed the basal diet supplemented with $2,2.5$ and $3 \mathrm{~g} \mathrm{Arg} / \mathrm{kg}$ diet, respectively, from one-day old to $40 \mathrm{wks}$ of age (17, 17.5 and $18 \mathrm{~g} \mathrm{Arg} / \mathrm{kg}$ diet) for the starter, (14.5, 15 and $15.5 \mathrm{~g}$ Arg $/ \mathrm{kg}$ diet) for the grower and $(14.8,15.3$ and $15.8 \mathrm{~g}$ $\operatorname{Arg} / \mathrm{kg}$ diet) for the finisher diet was used. However, the $5^{\text {th }}, 6^{\text {th }}$ and $7^{\text {th }}$ groups were fed the basal diet (15 g and12.5 Arg/kg diet) for the starter, grower diet and the basal diet supplemented with 2, 2.5 and $3 \mathrm{~g}$ Arg/ $\mathrm{kg}$ diet $(14.8,15.3$ and $15.8 \mathrm{~g} \mathrm{Arg} / \mathrm{kg}$ diet) for the finisher diets, respectively, only from 28 to 40 wks of age. Results indicated that hens fed Arg supplementation significantly improved feed conversion ratio (FCR) for all treatments except T2 and T3 groups in compared with control group. Egg production, egg mass and total leucocytes count was higher in treated hens from 28 to 40 wks of age than in control ones. Most semen quality parameters, fertility, hatchability and lymphocyte (L) ratio were improved by dietary treatments. However, hetrophils $(\mathrm{H})$ and $\mathrm{H} / \mathrm{L}$ ratio were decreased by Arg supplementation. Significant increase $(\mathrm{P} \leq 0.05)$ appear in NO trait, IGFI, LH and Testo hormones concentrations for hens in T6 and T7 from 28 to 40 wks of age in compared with treated hens from one-day old to $40 \mathrm{wks}$ of age (T2, T3 and T4) and the control group. While, there were no significant differences in live body weight, feed consumption, egg weight and egg quality traits among all treatments in compared with control group at 40 wks of age. It could be concluded that dietary Arg supplementation to SM hens from 28 to 40 might improve the egg production, reproductive performance and some semen quality parameters. Also, it might have a mediated effects on NO, IGF-I, LH and testosterone hormones levels.

Key Words: Arginine, Egg Production, Reproduction, Nitric Oxide and Some Hormones.

Corresponding author: drmohamedessa@yahoo.com 


\section{INTRODUCTION}

The L-arginine, one of the 20 most common natural amino acids (AA), is classified as a semi-essential or conditionally essential AA for mammals and essential AA for birds due to their inability to synthesize Arg. Moreover, The L-Arg requirement varied from lower than $0.70 \%$ of the diet for practical diets to nearly $1.8 \%$ for purified diets in which casein was the source of protein (Khajali and Wideman, 2010). Basiouni et al. (2006) found that feed conversion was improved and feed consumption was decreased in birds fed higher level of Arg (from 3 to $9 . \mathrm{g} / \mathrm{kg}$ of diet) over the normal requirements of the Leghorn breeds (NRC, 1994) in compared with the control. Also, they observed that egg weight and hen-day egg production was not affected. Youssef et al. (2015) found that dietary supplementation of L- Arg above NRC (1994) improved egg production, reproduction performance, enhanced cellular immunity and most semen parameters, while hand egg quality parameters was not affected. Guo et al. (2015) indicated that an increase in dietary Arg level from 9.0 to $13.5 \mathrm{~g} / \mathrm{kg}$ of diet correlated positively with nitric oxide (NO) production in broiler chicken. It has been reported that Arg could regulate the immune function via NO enzyme (Tsai et al., 2002). Moreover, L-Arg is a source of enzymes NO Syntheses is release to form NO, which has a great role in the way of blood transfusion in the blood vessels (Biliar, 1995). Likewise, Arg play important role in cell division and healing of wounds and immune effectiveness and hormones secretion (Stechmiller et al. 2005). Manwar et al. (2003) reported that level of NO in serum is linked to high egg production. Takahashi et al. (1994) noticed that Arg, as part of the hormone Arg vasotocin (neurohypophysial hormone) plays an important role in the initial contraction of hen's uterus through an increased binding to its receptor which might affect the process of oviposition in hen. Arginine is essential for sperm motility, metabolism, capacitation, acrosome reaction, and is a precursor for producing putrescine, spermine, and spermidine (Ko and Sabanegh, 2014). Fayh et al. (2007) reported that Arg supplementation during seven days was ineffective to augment both growth hormone $(\mathrm{GH})$ and IGF-I release in individual male adults. Basiouni (2009) found that feeding a $9 . \mathrm{g} / \mathrm{kg}$ of diet extra amount of Arg over the $0.89 \%$ arginine already present in the control diet to local Saudi chickens significantly $(\mathrm{P} \leq 0.05)$ increased mean LH level during the 6-9 hours before the time of oviposition in Arg treatment $(2.8 \mathrm{ng} / \mathrm{mL})$ in compared with control group (1.9 $\mathrm{ng} / \mathrm{mL}$ ), as well as, stimulatory effect of Arg on LH secretion maybe mediated through the stimulation of GnRH neurons in the hypothalamus and consequently, LH release. Kim et al. (2004) suggested that there is a possibility of IGF-I genotypes acting as a genetic marker for egg productivity of native Ogol chickens. Cremades et al. (2004) suggest that dietary Arg may be relevant to the anabolic action of testosterone in mice. Therefore, the present study was designed to assess the role of dietary supplementation with different levels of Arg on egg production, some semen quality parameters and IGF-I, LH and Testo hormones in Silver Montazah (SM) chickens during laying period.

\section{MATERIALS AND METHODS}

This experiment was conducted in Inshas Poultry Research Station, Animal Production Research Institute, Agricultural Research Center, Egypt during the period from February to May. 
A total of 420 hens and 105 cocks of SM chickens (Egyptian local strain) from day one to 40 wks of age were used. All chickens were randomly divided into 7 equal treatment groups each one included 3 replicates (each of 20 hens and 5 cocks). The $1^{\text {st }}$ group (T1) was fed the basal diet and served as the control group with no additional Arg (15, 12.5 and $12.8 \mathrm{~g}$ Arg $/ \mathrm{kg}$ diet) for the starter, grower and finisher diet, respectively. The $2^{\text {nd }}, 3^{\text {rd }}$ and $4^{\text {th }}$ groups were fed the basal diet supplemented with 2, 2.5 and $3 \mathrm{~g}$ Arg/ $\mathrm{kg}$ diet, respectively, from one-day old to 40 wks of age $(17,17.5$ and $18 \mathrm{~g} \mathrm{Arg} / \mathrm{kg}$ diet) for the starter, $(14.5,15$ and $15.5 \mathrm{~g}$ Arg $/ \mathrm{kg}$ diet) for the grower and (14.8, 15.3 and $15.8 \mathrm{~g} \mathrm{Arg} / \mathrm{kg}$ diet) for the finisher diet was used. However, the $5^{\text {th }}$, $6^{\text {th }}$ and $7^{\text {th }}$ groups were fed the basal diet (15 g and12.5 Arg/kg diet) for the starter, grower diet and the basal diet supplemented with $2,2.5$ and $3 \mathrm{~g} \mathrm{Arg} / \mathrm{kg}$ diet $(14.8,15.3$ and $15.8 \mathrm{~g} \mathrm{Arg} / \mathrm{kg}$ diet) for the finisher diets, respectively, only from 28 to 40 wks of age. (Table 2). LArginine monohydrochloride was assay $98.0 \%$, expiration date: 09/2017 and made in Germany. Each replicate was individually weighed, housed in separated floor pens $(185 \times 320 \mathrm{~cm})$ and submitted to the same managerial conditions in a windowed house with light cycle regimen of 16 hours light: 8 hours darkness. Birds were fed ad libitum and fresh water was provided continuously. The basal experimental diet was formulated to meet the nutrition requirements of chickens during the experimental period (from oneday old to 40 wks of age) according to the composition and calculated analysis of the experimental basal diet is present in Table (1).

\section{Measurements:-}

\section{Laying performance traits:}

Individual live body weights (LBW) in grams of hens and cocks were recorded at 28 wks of age and then weighed at interval periods of 4 wks. Moreover, feed consumption (FC, g), egg weight (EW, g) and egg number (EN) were recorded. In addition, feed consumption ( $\mathrm{g}$ diet/hen/day), feed conversion ratio (FCR, $\mathrm{g}$ feed/g eggs), and Egg mass (EM, g) were calculated.

\section{Egg quality parameters:}

A total of 105 eggs (15 eggs per each treatment) were taken after 40 wks of age to determine the interior and exterior egg quality parameters. Eggs were weighed individually then broken and the inner contents were placed on a leveled glass surface to determine the inner egg quality. Shell weight $\%$, shell thickness (mm), including shell membranes was measured using a micrometer at three locations on the egg (air cell, equator and sharp end), egg length $(\mathrm{mm})$, egg width $(\mathrm{mm})$, albumen weight $\%$, yolk weight $\%$, yolk height, $\mathrm{mm}(\mathrm{YH})$, yolk diameter $(\mathrm{mm})$.

\section{Semen quality:}

Semen samples were collected randomly from 42 cocks $(6$ cocks /treatment) at 40 wks of age using the massage method. Semen samples were examined following method according to Kalamah et al., (2000).

Semen quality parameters were: The ejaculate volume, initial semen $\mathrm{pH}$, mass motility score, percentage of live and abnormal sperm, sperm concentration, total sperm/ejaculate x $10^{9}$, Total abnormal sperm/ejaculate $\times 10^{9}$ and total live sperm/ejaculate x $10^{9}$.

\section{Reproduction performance:}

Eggs were daily collected from each treatment (100 eggs) during the last week and incubated to determine fertility and hatchability percentages. Fertility data were collected after each insemination and fertility rate was described as the number of fertile eggs to the number of eggs placed in the incubator. Hatchability was determined at the end of incubation. Hatchability of fertile eggs was found via a similar way in which the number of live chicks was divided by the number of 
fertile eggs kept in the incubator. Hatchability of total eggs was calculated from the number of live chicks divided by the number of eggs placed in the incubator.

\section{Some blood traits:}

At the end of the experimental period (40 wks of age) six chicks of each group were randomly chosen. Blood samples were collected from wing vain of each bird in two heparinized test tubes. Blood of the first tube was used to evaluate the total count of red and white blood cells as well as the differential counts of leucocytes (lymphocyte and heterophil) while the second one was centrifuged at $3000 \mathrm{rpm}$ for 20 minutes. The separated plasma was stored at $-20^{\circ} \mathrm{C}$ until assayed for blood traits included in this study were total erythrocytes count (RBCs), hemoglobin concentration $(\mathrm{Hb})$, hematocrit volume (Hc), total leucocytes count (WBCs), hetrophils $(\mathrm{H} \%)$, lymphocyte ratio $(\mathrm{L} \%)$, and hetrophils to lymphocyte ratio (H/L). All measurements conducted according to Full Automated Ceutac.

\section{Nitric oxide concentration and hormones:}

Nitric oxide was determined according to Colorimetric Determination of Nitrite (Montgomery and Dymock 1961) and Insulin-like growth factor (IGF-I) hormone was determined according to the manufacture recommendations of commercial kits. LH hormone was determined in serum by using chicken luteotropic hormone (LH) Elisa commercial Kits, China, while testosterone determined in serum by using Ria testosterone, direct. Beckman Coulter Company.

\section{Statistical analysis:}

Data were subjected to one-way analysis of variance using SAS (2001). Differences among means were detected by using Duncan's multiple range test (Duncan, 1955). The percentage values were transferred to percentage angle using arcsine equation before subjected to statistical analysis, and then actual means are presented. The following model was used:

$Y_{i j}=G+T_{i}+e_{i j}$.

Where, $Y_{i j}=$ observation for each dependent variable; $\mathrm{G}=$ General mean;

$\mathrm{T}_{\mathrm{i}}=$ Treatment effects $(\mathrm{i}=1,2 \ldots$ and 7$) ; \mathrm{e}_{\mathrm{ij}}$ $=$ Random error.

\section{RESULTS AND DISCUSSIONS}

\section{Laying performance traits:}

Effect of dietary Arg supplementation

to SM hens diets on production performance are summarized in Table (3). The data show that Arg levels did not affect significantly on LBW and FC traits. These findings were in accordance with Basiouni et al., (2006) who found that at the highest Arg (9.g $/ \mathrm{kg}$ of diet) in local Saudi chickens feed did not influence LBW at 40 wks of age. Moreover, (Wu et al. 2011 ; Youssef et al., 2015), indicated that feed intake were not significantly affected by diets containing increased levels of Arg. Hens fed Arg of T4, T5, T6 and $\mathrm{T} 7$ groups had significantly $(\mathrm{P} \leq 0.05)$ better FCR as compared with those fed control diet during experimental period. The FCR of T6 and T7 were significantly improved in compared with the control by approximately 13 and $15 \%$, respectively. These results agree with those obtained by Youssef et al., (2015) who reported that feed conversion significantly improved, as the dietary L-Arg level increased. Positive effect similar to that with Arg supplementation on morphometry of the duodenum mucosa was observed on the live weight of 7-day-old birds, demonstration that Arg supplementation is involved in the maintenance of the duodenum mucosa and that this effect may be associated to the better performance observed at this age (Murakami et al., 2006). Moreover, the mechanism involved in the intestine cell turnover by nutrients is little understood yet. Also, there is evidence for the 
participation of adjustment mechanisms between intrinsic and primary extrinsic afferent neurons and the central nervous system in addition to enzyme gene transcription mechanisms, and even gene expression, as specifically reported for some amino acids, such as Arg (Wu 2009). On contrarily, Basiouni et al., (2006) found that FCR trait was not affected by increasing dietary Arg in local Saudi laying hens.

These results may be refer to that the requirements of Arg in improved strain of chicken such as SM may be higher than other layer chicken presented in the NRC, or that improving FCR may be due with relationship between egg mass and FCR when egg mass increase FCR decreased.

No significant effects of Arg supplementation on EW were observed at 40 wks of age (Table 3 ). These results are in harmony with those reported by Youssef et al., 2015, Basiouni et al., 2006 and (Najib and Basiouni 2004) who found no significant effect of feeding different levels of Arg ranging from 0 to $2.5 \%$ on average EW in local hens. On the other hand, results show significant $(\mathrm{P} \leq 0.05) \quad$ differences among the experimental groups in egg production percentage (EP \%) due to Arg supplementation to SM layer diets. However, EP \% and egg mass were significantly $(\mathrm{P} \leq 0.05) \quad$ improved by feeding diets supplemented with Arg in hens fed diet of T5, T6 and T7 during the experimental period as in compared with the control group. The increases in the egg mass at 40 wks of age in hens fed the basal diet supplemented with 2,0 2.5 and $3.0(\mathrm{~g} / \mathrm{kg}$ diet $)$ Arg from 28 to $40 \mathrm{wks}$ of age, respectively, were $10.4,14.2$ and $15.9 \%$, respectively compared with control group. These results were in agreement with the findings of Youssef et al., (2015) who noticed that adding Arg to the diet of two local strains Fayoumi and $\mathrm{GM}$ at levels 0.14 and $0.28 \mathrm{~g} / \mathrm{kg}$ of diet resulted in significant increase $(\mathrm{P} \leq 0.05)$ in
EP \% and egg mass at 52 wks of age, as well as, increasing Arg level to local Saudi laying hens to $9 . \mathrm{g} / \mathrm{kg}$ of diet over that required for the Leghorn breed requirements was found to improve henday production percent (Silva et al., 2012; Basiouni et al., 2006; Najib and Basiouni 2004). In this context, stimulatory effect of Arg on luteinizing hormone ( $\mathrm{LH})$ secretion maybe mediated through the stimulation of GnRH neurons in the hypothalamus and consequently, LH release. (Basiouni, 2009). On the other hands, Sharideh et al., (2015) found that dietary supplementation of Arg (from 7.3 to $16.3 \mathrm{~g} / \mathrm{kg}$ diet) failed to change the rate of egg production. The present results show that the egg production traits was markedly improved in Arg supplemented group throughout the experimental period from 28 to 40 wks of age.

\section{Egg quality traits:}

Table (4) exhibit the results of the effect of adding different levels of Arg to the diet of laying hens on egg length, egg width, shell thickness, shell weight \%, albumen height, albumen weight \%, yolk height, yolk diameter and yolk weight $\%$, It was noticed from this Table that there were insignificant differences between different treatment. These results clearly indicated that there are no negative effects of adding Arg to laying hens diet on egg quality of birds. In addition, these results are in harmony with those reported by Youssef et al., (2015) and Silva et al., (2012) who established that the dietary Arg supplementation (from $0.943 \%$, to $1.543 \%$ digestible Arg) did not have significant effect on egg quality parameters in laying hens.

\section{Semen quality traits:}

The results in Table (5) summarized the effect of Arg supplementation on ejaculate volume, semen $\mathrm{PH}$, sperm motility, live sperm\%, abnormal sperm \%, sperm concentration, total sperm/ejaculate, total live sperm/ejaculate 
and total abnormal sperm/ejaculate of SM cocks at 40 wks of age. The results show that the increment in ejaculate volume, sperm motility, live sperm $\%$ and total sperm/ejaculate at 40 wks of age were significantly $(\mathrm{P} \leq 0.05)$ higher for the most treated groups (fromT3 to $\mathrm{T} 7$ ) in compared with control group. In addition, all treated groups were recorded the significant $(\mathrm{P} \leq 0.05)$ higher in sperm concentration and total live sperm/ejaculate in compared with control group. Whereas, control group was significantly $(\mathrm{P} \leq 0.05)$ the highest in abnormal sperm \% of SM chickens compared to all other groups. In this respect, semen $\mathrm{PH}$ and total abnormal sperm/ejaculate were not significant affected by SM Arg supplementation in diets compared with the control group. In this context, cocks received (2.5 and $3.0 \mathrm{~g}$ $\mathrm{Arg} / \mathrm{kg}$ diet) in their diets had recorded significantly $(\mathrm{P} \leq 0.05)$ higher sperm motility value by about 42.9 and $48.9 \%$ from 28 to 40 wks of age respectively as compared with the control group.

These results agree with the findings of (Youssef et al., 2015) who reported that semen quality (Semen volume, motility and sperm concentration) increased significantly by $\mathrm{Arg}$ supplementation. However, abnormality reduced significantly by the dietary Arg supplementation in diets. Das et al., (2006) found that in the fowl oviduct, sperm are stored for a prolonged period in the sperm storage tubules (SST), and hence, it seems that dietary supplementation of Arg might be involved in providing an optimal milieu for storage of spermatozoa in the SST. As well as, Steven (2000) reported that polyamines are essential for sperm motility. Nitric oxide has a dual function, being both a cytotoxic and necessary molecule for normal sperm production. Moreover another metabolic pathway that involves L-Arg is the synthesis of polyamines. Polyamines (putrescine, spermine and spermidine) function in membrane transport (Schaefer and Seidenfeld, 1987) cell growth, cell proliferation and cell differentiation (Schuber 1989). Spermidine and spermine are highly concentrated in cell types that have a high demand on oxidant protection, such as sperm (El-Taieb et al., 2009)

Fertility and hatchability traits:

Results obtained from Table (6) indicated that the inclusion of Arg in diets significantly improved $(\mathrm{P} \leq 0.05)$ Fertility and hatchability $\%$ of SM laying hens at 40 wks of age compared with those of control diet. The highest Fertility and hatchability $\%$ were recorded for hens of T6 and T7 groups as compared with control group whereas; there were insignificant differences among other treatments in these traits. These results supported with findings of Youssef et al., (2015) who reported dietary supplementation with different levels of L-Arg resulted in significant increase in fertility and hatchability $\%$ as compared with control group. Also, Sharideh et al., (2015) found that adding Arg to the broiler breeder diet increased 10\% sperm penetration (SP), higher Fertility is directly correlated with the SP and rate in the inner perivitelline layer (IPL) overlying the germinal disc $(\mathrm{P} \leq 0.05)$. This may be due to L-Arg was critical for the growth of chicken embryo (Toghyani et al., 2012). On contrary, Silva et al., (2012) reported that the dietary Arg supplementation (from $0.943 \%$, to $1.543 \%$ digestible Arg) did not have significant effect on Fert and hatch in laying hens.

\section{Some blood traits:}

The main effects of Arg on the RBCs, $\mathrm{Hb}$ and $\mathrm{Hc}$ values were not significant. However, the effects of Arg on the WBC, $\mathrm{H} \%, \mathrm{~L} \%$, and $\mathrm{H} / \mathrm{L}$ were significantly increased (Table 7). Dietary supplementation with different levels of Arg (T6 andT7 groups) resulted in 
significant increase in WBC. Also, the effects of (T5, T6 and T7 groups) on L \% cells were significant. However, T6 and T7 groups had significantly $(\mathrm{P} \leq 0.05)$ increased on $\mathrm{H} \%$ cells compared with control group. Meanwhile, all treated groups except $\mathrm{T} 4$ group were recorded the significant $(\mathrm{P} \leq 0.05)$ lower in $\mathrm{H} / \mathrm{L}$ ratio in compared with control group. These results are in agreement with Youssef et al., (2015) noticed that supplemented Arg up to $4 \%$ as a percentage of dietary LArg had no effect on RBCs, $\mathrm{Hb}$ and hematocrit values of laying hens. Also, reported that resulted in significant increase $(\mathrm{P} \leq 0.05)$ in total WBC, $\mathrm{H}$ cells $\%$ and significant decrease $(\mathrm{P} \leq 0.05)$ of $\mathrm{L}$ cells $\%$ and hetrophils to lymphocyte ratio ( $\mathrm{H} / \mathrm{L}$ ratio) as compared with control group. The outcome of this study is in accordance with the findings of Corzo and Kidd (2003) who indicated that chicks have a considerable critical need for dietary at an early age which possibly was associated with immune system development and early microbial challenges. However, Abdukalykova and Ruiz-Feria (2006) demonstrated that high level of Arg can accelerate antibody production in broiler chickens. Further study by Emadi et al., (2011) reported that the increase in Arg level in the diet (basal diet supplemented with 2.5 times NRC (1994) level of Arg) caused significant enhancement in immune response. Wherefore, Miller (2004) indicated that function performed by the bursa of fabricius in broiler chickens and he believed that the thymus could carry out the only thymus-derived lymphocytes could be involved in the antibody production. Also, Nitric oxide can enhance the body's non-specific immunity by nonspecifically killing pathogens such as bacteria, fungi, parasites and tumor cells. More importantly, NO regulates the synthesis and secretion of some immune cytokines, such as tumor necrosis factor (TNF), prostaglandin E2 (PGE2), interleukin (IL) and interferon (IFN), which leads to a more wide influence on the immune function (Li et al., 2009).

\section{Blood plasma Nitric oxide and hormones:}

The average values of NO, IGF-I, LH and testosterone hormone during different periods of age of SM laying hens affected by using Arg in diets are presented in (Table 8). Control group (T1) recorded worst NO compared with the other groups. While, both of $\mathrm{T} 6$ and $\mathrm{T} 7$ groups were significantly $(\mathrm{P} \leq 0.05)$ recorded the better values in NO trait in compared with all other groups at 40 wks of age. In this respect, Atakisi, et al., (2009) ; Guo et al., (2015) reported that the dietary Arg supplementation in diets significantly $(\mathrm{P} \leq 0.01)$ increased $\mathrm{NO}$ in laying quails. Improving semen quality via L-Arg may be due to a positive effect of NO donating amino acids like L-Arg, attributed to improve blood circulation and alleged reduction of oxidative stress (Ciftci et al., 2009). Arginine-derived NO plays a number of roles, including lipid metabolism through increasing the expression of genes involved in fatty acid oxidation and inhibiting the expression of genes responsible for fatty acid synthesis (Khalaji et al., 2013). Also, NO induced luteinizing hormone (LH) secretion occurs in the pituitary gland. (Al-Daraji and Tahir, 2014). Nitric oxide plays a crucial role in protecting various sperm functions such as motility, viability, capacitation and antioxidant against reactive oxygen species. Also, who reported that NO plays a crucial role in protecting various sperm functions such as motility, viability, capacitation and antioxidant against reactive oxygen species (Siddique and Atreja 2013).

On the other hand, hens fed on T6 and $\mathrm{T} 7$ groups gave significantly $(\mathrm{P} \leq 0.05)$ the best IGF-I value than other treatments groups at $40 \mathrm{wks}$ of age. In this respect, Silva et al., (2012) reported that Arg is also considered a powerful secretagogue, 
increasing the release of insulin, growth hormone, and IGF-A in the blood stream.

Kim et al., (2004) ; Soliman et al., (2011) reported that IGF-I hormone is associated with egg production of chicken. Likewise, (Le Roith et al., 2001) and (Kim et al., 2004) found that insulin-like growth factors IGF1 are involved in the regulation of ovulation rate, ovary growth and steroid hormone production and ovarian follicular development in chickens, and a relationship between IGFI genotype. Cremades et al., (2004) suggest that Arg deficiency produced an opposite effect in the expression of IGF-I and IGF-binding protein 1 in the liver and kidney. Concerning $\mathrm{LH}$ and testosterone hormone in (Table 8), the results show that T5, T6, T7 groups had significantly $(\mathrm{P} \leq 0.05)$ higher LH and testosterone hormones at 40 wks of age than control group. These results were agreement with the results of many investigators who used the same or nearly the same doses via diets. Basiouni, (2009) showed that feeding a $2 \%$ extra amounts of Arg ( over the $0.89 \%$ Arg already present in the control diet) to local Saudi hens significantly $(\mathrm{P} \leq 0.05)$ increased mean LH level during the 6-9 hours before the time of oviposition in Arg treated (2.8 $\mathrm{ng} \mathrm{mL}^{-1}$ ) in compared with control group

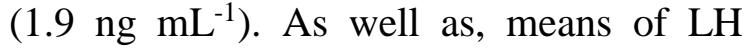
amplitude was also found to be higher in Arg treated in compared with control group, These results are also in line with previous reports involving pre-pubertal goats was the infusion of Arg was found to be able to increase mean of LH pulse frequency and consequently increase mean LH levels Basiouni, et al., (1999). Furthermore, dietary Arg may be relevant to the anabolic action of Testo, and suggest that this effect may be mediated by changes in IGF-I system Cremades et al., (2004).

In the present study, show that NO, IGF-I, LH and Testo hormones levels of chickens fed diets supplemented with (2.0, 2.5 and $3.0 \mathrm{~g} \mathrm{Arg} / \mathrm{kg}$ diet) in their diets from 28 to 40 wks of age were higher than in control group with ranged from 9.7 to $48.1,1.5$ to $16.4,24.5$ to 69.9 and 57 to $65.9 \%$, respectively. It seems that higher NO, IGF-I, LH and Testo hormones are directly correlated with the Arg supplementation from 28 to 40 wks of age. It is suggested that this beneficial effects of Arg may be relevant to liver functions or the stimulation of GnRH neurons in the hypothalamus. Further studies are necessary to be repeated on commercial breed of hens to examine the effect of Arg feeding on these traits.

In conclusion, dietary supplementation Arg from 28 to 40 wks of age might has the potential to improve egg production, reproductive traits, semen physical characteristics and some plasma hormones levels. Although adding Arg to SM hens' diets did not affect body weight, feed consumption, egg weight and egg quality traits during laying period from 28 to 40 wks of age. 
Table (1): The composition of the experimental basal diets.

\begin{tabular}{|l|c|c|c|}
\hline \multirow{2}{*}{ Ingredients } & \multicolumn{3}{|c|}{ Percentage (\%) } \\
\cline { 2 - 4 } & Starter diet & Grower diet & Layer diet \\
\hline Yellow corn & 59.84 & 63.91 & 61.57 \\
Soya bean 44\% & 24.20 & 14.50 & 17.00 \\
Wheat bran & 8.20 & 18.10 & 6.70 \\
Corn gluten 60\% & 4.00 & ----- & 4.50 \\
Di Ca P export & 1.53 & 1.12 & 1.39 \\
Lime stone & 1.52 & 1.67 & 8.16 \\
Salt & 0.37 & 0.37 & 0.37 \\
*Premix & 0.30 & 0.30 & 0.30 \\
L Methionine & 0.04 & 0.03 & 0.01 \\
Total & 100.00 & 100.00 & 100.00 \\
\hline Calculated values (\%) & \multicolumn{3}{|c|}{} \\
\hline Protein & 19.0 & 14.0 & 16.5 \\
Metabolizable energy (M.E.) & 2800 & 2700 & 2699 \\
Crude fiber (C. F.) & 4.124 & 4.518 & 3.468 \\
Ether extract & 3.052 & 3.369 & 2.964 \\
Calcium & 0.995 & 0.945 & 3.399 \\
Available Phosphorous & 0.447 & 0.377 & 0.397 \\
Total Phosphorous & 0.692 & 0.635 & 0.610 \\
Sodium & 0.161 & 0.166 & 0.164 \\
Arginine & 1.50 & 1.25 & 1.28 \\
Lysine & 0.949 & 0.697 & 0.730 \\
Methionine & 0.403 & 0.295 & 0.335 \\
Methionine \& cysteine & 0.734 & 0.558 & 0.619 \\
\hline
\end{tabular}

*Premix added to the $1 \mathrm{~kg}$ of diet including Vit.A 10000 I.U; vit. D3 2000 I.U; vit. E 15 $\mathrm{mg}$; vit. K3 $1 \mathrm{mg}$; vit B1 1mg; vit. B2 $5 \mathrm{mg}$; vit. B12 $10 \mu \mathrm{g}$; vit B6 1.5mg; Niacin 30mg; Pantothenic acid $10 \mathrm{mg}$; folic acid $1 \mathrm{mg}$; Biotin $50 \mu \mathrm{g}$; choline $300 \mathrm{mg}$; zinc $50 \mathrm{mg}$; copper $4 \mathrm{mg}$; iodine $0.3 \mathrm{mg}$; iron $30 \mathrm{mg}$; selenium $0.1 \mathrm{mg}$; manganese $60 \mathrm{mg}$; cobalt $0.1 \mathrm{mg}$ and carrier $\mathrm{CaCo} 3$ up to $1 \mathrm{~kg}$.

**According to Feed composition tables for Animal \& Poultry feedstuffs used in Egypt (2001). 
Table (2) Calculated values of dietary Arg and supplemented Arg in Silver Montazah strain fed diets diet supplemented with different values of Arg (g/kg diet)

\begin{tabular}{|l|l|l|l|l|l|l|l|}
\hline Treatments & T1(control) & T2 & T3 & T4 & T5 & T6 & T7 \\
\hline Starter diet & 15.0 & 17.0 & 17.5 & 18.0 & 15.0 & 15.0 & 15.0 \\
Grower diet & 12.5 & 14.0 & 14.5 & 15.0 & 12.5 & 12.5 & 12.5 \\
Layer diet & 12.8 & 14.8 & 15.3 & 15.8 & 14.8 & 15.3 & 15.8 \\
\hline
\end{tabular}

Table (3): Effect of dietary arginine supplementation on the performance of Silver Montazah laying hens during the experimental period

\begin{tabular}{|c|c|c|c|c|c|c|c|c|}
\hline Item & T1 & T2 & T3 & T4 & T5 & T6 & T7 & SEM \\
\hline $\begin{array}{l}\text { Initial body } \\
\text { weight }(\mathrm{g})\end{array}$ & 1327.33 & 1324.00 & 1328.28 & 1330.34 & 1333.25 & 1325.72 & 1319.31 & 14.971 \\
\hline $\begin{array}{l}\text { Final body } \\
\text { weight }(\mathrm{g})\end{array}$ & 1460.21 & 1501.11 & 1494.17 & 1473.09 & 1459.31 & 1476.13 & 1486.07 & 16.573 \\
\hline $\begin{array}{l}\text { Feed } \\
\text { consumption } \\
\text { (g/hen/day) }\end{array}$ & 104.33 & 101.46 & 102.27 & 102.18 & 103.49 & 103.47 & 103.01 & 1.341 \\
\hline $\begin{array}{l}\text { Feed } \\
\text { conversion } \\
(\mathrm{g} \text { feed/g } \\
\text { egg) }\end{array}$ & $3.95^{\mathrm{a}}$ & $3.66^{\mathrm{ab}}$ & $3.62^{\mathrm{ab}}$ & $3.59^{b c}$ & $3.55^{b c}$ & $3.43^{\mathrm{c}}$ & $3.37^{\mathrm{c}}$ & 0.051 \\
\hline $\begin{array}{l}\text { Egg } \\
\text { production } \\
(\%)\end{array}$ & $51.47^{\mathrm{c}}$ & $53.96^{\mathrm{bc}}$ & $54.03^{\mathrm{bc}}$ & $54.44^{\mathrm{bc}}$ & $56.00^{\mathrm{ab}}$ & $57.59^{\mathrm{a}}$ & $58.45^{\mathrm{a}}$ & 1.518 \\
\hline $\begin{array}{l}\text { Egg weigh } \\
\text { (g) }\end{array}$ & 43.05 & 43.20 & 43.91 & 43.98 & 43.69 & 43.96 & 43.95 & 0.129 \\
\hline $\begin{array}{l}\text { Egg mass (g/ } \\
\text { hen/ day) }\end{array}$ & $26.39^{b}$ & $27.73^{b}$ & $28.24^{\mathrm{ab}}$ & $28.50^{\mathrm{ab}}$ & $29.13^{\mathrm{a}}$ & $30.14^{\mathrm{a}}$ & $30.58^{\mathrm{a}}$ & 21.507 \\
\hline
\end{tabular}

a, b... Means within each row with different superscript are significantly different $(\mathrm{P} \leq 0.05)$. 
Table (4): Effect of dietary arginine supplementation on external and internal egg quality of Silver Montazah laying hens at 40 wks of ages.

\begin{tabular}{|c|c|c|c|c|c|c|c|c|}
\hline Item & T1 & $\mathbf{T 2}$ & T3 & T4 & T5 & T6 & T7 & SEM \\
\hline \multicolumn{9}{|c|}{ External egg quality traits } \\
\hline Egg length $(\mathrm{mm})$ & 53.57 & 52.45 & 52.62 & 51.07 & 53.10 & 52.28 & 52.67 & 0.794 \\
\hline Egg width (mm) & 41.55 & 41.50 & 41.08 & 39.97 & 40.93 & 41.15 & 40.82 & 0.530 \\
\hline $\begin{array}{l}\text { Shell thickness } \\
(\mathrm{mm})\end{array}$ & 0.368 & 0.378 & 0.372 & 0.377 & 0.375 & 0.372 & 0.373 & 0.0036 \\
\hline Shell weight $(\%)$ & 13.33 & 13.83 & 13.49 & 13.44 & 13.59 & 13.57 & 13.93 & 0.816 \\
\hline \multicolumn{9}{|c|}{ Internal egg quality traits } \\
\hline $\begin{array}{l}\text { Albumen height } \\
(\mathrm{mm})\end{array}$ & 6.91 & 6.59 & 6.74 & 7.99 & 6.91 & 6.70 & 6.74 & 0.742 \\
\hline $\begin{array}{l}\text { Albumen weight } \\
\text { (\%) }\end{array}$ & 56.11 & 56.55 & 54.28 & 52.47 & 54.40 & 53.94 & 54.71 & 1.271 \\
\hline Yolk height $(\mathrm{mm})$ & 17.03 & 16.83 & 16.89 & 16.22 & 17.08 & 16.65 & 16.48 & 0.421 \\
\hline $\begin{array}{l}\text { Yolk diameter } \\
(\mathrm{mm})\end{array}$ & 38.67 & 38.93 & 38.77 & 39.45 & 38.75 & 38.98 & 39.15 & 0.773 \\
\hline Yolk weight (\%) & 30.57 & 30.62 & 31.24 & 31.09 & 31.01 & 31.50 & 31.37 & 0.826 \\
\hline
\end{tabular}

$\mathrm{a}, \mathrm{b} . .$. Means within each row with different superscript are significantly different $(\mathrm{P} \leq 0.05)$.

Table (5): Effect of dietary arginine supplementation on semen quality traits of Silver Montazah cocks at 40 wks of ages.

\begin{tabular}{|c|c|c|c|c|c|c|c|c|}
\hline Item & T1 & $\mathbf{T 2}$ & $\mathbf{T 3}$ & T4 & T5 & T6 & T7 & SEM \\
\hline $\begin{array}{l}\text { Ejaculate volume } \\
(\mathrm{ml})\end{array}$ & $0.292^{\mathrm{c}}$ & $0.363^{\mathrm{bc}}$ & $0.392^{b}$ & $0.397^{b}$ & $0.408^{\mathrm{ab}}$ & $0.442^{\mathrm{ab}}$ & $0.513^{a}$ & 0.037 \\
\hline Semen $\mathrm{pH}$ & 7.50 & 7.33 & 7.34 & 7.46 & 7.71 & 7.54 & 7.52 & 0.218 \\
\hline $\begin{array}{l}\text { Sperm motility } \\
\text { score }\end{array}$ & $2.80^{\mathrm{c}}$ & $3.17^{b c}$ & $3.33^{\mathrm{b}}$ & $3.25^{\mathrm{b}}$ & $3.83^{\mathrm{a}}$ & $4.00^{\mathrm{a}}$ & $4.17^{\mathrm{a}}$ & 0.367 \\
\hline Live sperms (\%) & $74.33^{c}$ & $\begin{array}{l}81.00 \\
\text { bc }\end{array}$ & $89.17^{\mathrm{a}}$ & $\begin{array}{l}87.17 \\
\text { ab }\end{array}$ & $90.50^{\mathrm{a}}$ & $87.17^{a b}$ & $92.00^{\mathrm{a}}$ & 2.451 \\
\hline $\begin{array}{l}\text { Abnormal sperms } \\
(\%)\end{array}$ & $18.83^{\mathrm{a}}$ & $14.50^{\mathrm{b}}$ & $14.17^{\mathrm{b}}$ & $13.17^{b}$ & $12.50^{\mathrm{b}}$ & $14.83^{b}$ & $12.83^{b}$ & 1.244 \\
\hline $\begin{array}{l}\text { Sperm } \\
\text { concentration } \\
\times 10^{6}\end{array}$ & $2.78^{\mathrm{b}}$ & $3.33^{\mathrm{a}}$ & $3.72^{\mathrm{a}}$ & $3.79^{\mathrm{a}}$ & $3.56^{\mathrm{a}}$ & $3.79^{\mathrm{a}}$ & $3.86^{\mathrm{a}}$ & 0.171 \\
\hline $\begin{array}{l}\text { Total } \\
\text { sperms/ejaculate }\end{array}$ & $0.803^{b}$ & $0.838^{b}$ & $1.510^{\mathrm{a}}$ & $1.638^{\mathrm{a}}$ & $1.757^{\mathrm{a}}$ & $1.502^{\mathrm{a}}$ & $1.650^{\mathrm{a}}$ & 0.172 \\
\hline $\begin{array}{l}\text { Total live } \\
\text { sperms/ejaculate }\end{array}$ & $2.102^{\mathrm{c}}$ & $2.707^{b}$ & $3.330^{\mathrm{ab}}$ & $\begin{array}{l}3.300 \\
\mathrm{ab}\end{array}$ & $3.222^{\mathrm{ab}}$ & $3.342^{a b}$ & $3.555^{\mathrm{a}}$ & 0.204 \\
\hline $\begin{array}{l}\text { Total abnormal } \\
\text { sperms/ejaculate }\end{array}$ & 0.515 & 0.488 & 0.533 & 0.503 & 0.440 & 0.562 & 0.487 & 0.047 \\
\hline
\end{tabular}

a, b.. Means within each row with different superscript are significantly different $(\mathrm{P} \leq$ $0.05)$. 
Table (6): Effect of dietary arginine supplementation on fertility and hatchability percentage of Silver Montazah laying hens at 40 wks of age.

\begin{tabular}{|c|c|c|c|c|c|c|c|c|}
\hline Item & T1 & $\mathbf{T 2}$ & T3 & T4 & T5 & T6 & T7 & SEM \\
\hline Fert (\%) & $89.07^{b}$ & $90.32^{b}$ & $92.56^{\mathrm{ab}}$ & $92.53^{\mathrm{ab}}$ & $93.00^{\mathrm{ab}}$ & $94.75^{a}$ & $94.00^{\mathrm{a}}$ & 1.538 \\
\hline $\begin{array}{l}\text { Hatch of all eggs } \\
(\%)\end{array}$ & $79.64^{b}$ & $79.02^{b}$ & $79.84^{b}$ & $80.32^{b}$ & $83.88^{\mathrm{ab}}$ & $86.67^{\mathrm{a}}$ & $86.00^{\mathrm{a}}$ & 1.569 \\
\hline $\begin{array}{l}\text { Hatch of fertile } \\
\text { eggs }(\%)\end{array}$ & $87.33^{c}$ & $88.29^{c}$ & $89.71^{\mathrm{c}}$ & $91.31^{\mathrm{bc}}$ & $91.28^{b c}$ & $93.72^{a b}$ & $93.68^{\mathrm{ab}}$ & 1.351 \\
\hline
\end{tabular}

a, b... Means within each row with different superscript are significantly different $(\mathrm{P} \leq 0.05)$.

Fertility \% (Fert), Hatchability of all eggs (Hatch of all eggs) and Hatchability of fertile eggs (Hatch of fertile eggs).

Table (7): Effect of dietary arginine supplementation on some blood traits of Silver Montazah laying hens at 40 wks of age

\begin{tabular}{|c|c|c|c|c|c|c|c|c|}
\hline Item & T1 & T2 & T3 & T4 & T5 & T6 & T7 & SEM \\
\hline $\begin{array}{l}\text { RBCs } \\
\left(\mathrm{x} 10^{6} / \mathrm{mm}^{3}\right)\end{array}$ & 2.177 & 2.200 & 2.367 & 2.133 & 2.037 & 2.333 & 2.607 & 0.197 \\
\hline $\mathrm{Hb}(\mathrm{g} / \mathrm{dl})$ & 12.33 & 11.93 & 13.33 & 11.63 & 11.43 & 12.97 & 14.30 & 0.954 \\
\hline $\mathrm{Hc}(\%)$ & 38.87 & 39.07 & 35.00 & 35.77 & 39.13 & 33.67 & 37.07 & 2.670 \\
\hline $\begin{array}{l}\text { WBCs } \\
\left(\times 10^{3} / \mathrm{mm}^{3}\right)\end{array}$ & $13.72^{\mathrm{c}}$ & $14.95^{\mathrm{bc}}$ & $15.26^{\mathrm{bc}}$ & $15.16^{\mathrm{bc}}$ & $15.77^{\mathrm{b}}$ & $17.94^{\mathrm{a}}$ & $17.86^{\mathrm{a}}$ & 0.665 \\
\hline \multicolumn{9}{|c|}{ Differential leucocyte count $(\%)$} \\
\hline $\mathrm{H}(\%)$ & $30.93^{\mathrm{a}}$ & $28.70^{\mathrm{ab}}$ & $28.13^{\mathrm{ab}}$ & $29.10^{\mathrm{ab}}$ & $28.27^{\mathrm{ab}}$ & $27.47^{b}$ & $27.63^{\mathrm{b}}$ & 0.548 \\
\hline $\mathrm{L}(\%)$ & $59.03^{b}$ & $60.40^{\mathrm{b}}$ & $59.73^{\mathrm{b}}$ & $59.27^{\mathrm{b}}$ & $61.37^{\mathrm{ab}}$ & $62.20^{\mathrm{a}}$ & $63.10^{\mathrm{a}}$ & 0.496 \\
\hline $\mathrm{H} / \mathrm{L}$ ratio & $0.524^{\mathrm{a}}$ & $0.475^{\mathrm{b}}$ & $0.471^{\mathrm{b}}$ & $0.491^{\mathrm{ab}}$ & $0.461^{b c}$ & $0.442^{b c}$ & $0.438^{\mathrm{c}}$ & 0.0088 \\
\hline
\end{tabular}

a, b.... Means within each row with different superscript are significantly different $(\mathrm{P} \leq 0.05)$. Erythrocytes count (RBCs), hemoglobin concentration (Hb), Heamatocrit $(\mathrm{Hc})$, total leucocytes count (WBCs), Heterophils (H) and Lymphocytes (L).

Table (8): Effect of dietary arginine supplementation on nitric oxide and plasma IGF-1 and luteinizing hormone (LH) and Testosterone of Silver Montazah laying hens at 40 wks of age

\begin{tabular}{|c|c|c|c|c|c|c|c|c|}
\hline Item & T1 & $\mathbf{T 2}$ & T3 & T4 & T5 & T6 & T7 & SEM \\
\hline $\begin{array}{l}\text { Nitric oxide } \\
\text { (umol/ml) }\end{array}$ & $21.40^{\mathrm{c}}$ & $23.17^{b c}$ & $24.10^{\mathrm{bc}}$ & $22.63^{b c}$ & $\begin{array}{c}23.47 \\
\mathrm{bc}\end{array}$ & $30.74^{\mathrm{a}}$ & $31.70^{\mathrm{a}}$ & 2.733 \\
\hline IGF-1 (ng/ml) & $22.23^{b}$ & $22.57^{\mathrm{b}}$ & $22.77^{\mathrm{b}}$ & $23.13^{\mathrm{b}}$ & $22.57^{b}$ & $25.73^{\mathrm{a}}$ & $25.87^{\mathrm{a}}$ & 0.2063 \\
\hline LH (ng/ml) & $0.163^{\mathrm{c}}$ & $0.177^{b c}$ & $0.170^{\mathrm{bc}}$ & $0.190^{b c}$ & $0.203^{b}$ & $0.277^{\mathrm{a}}$ & $0.263^{\mathrm{a}}$ & 0.0209 \\
\hline $\begin{array}{l}\text { Testosterone } \\
(\mathrm{ng} / \mathrm{ml})\end{array}$ & $2.270^{\mathrm{c}}$ & $2.287^{b c}$ & $2.640^{\mathrm{bc}}$ & $2.700^{b c}$ & $3.567^{\mathrm{a}}$ & $3.600^{\mathrm{a}}$ & $3.767^{\mathrm{a}}$ & 0.120 \\
\hline
\end{tabular}

$\mathrm{a}, \mathrm{b} \ldots$... Means within each row with different superscript are significantly different $(\mathrm{P} \leq 0.05)$. 


\section{REFERENCES}

Abdukalykova, S. and C. Ruiz-Feria (2006). Arginine and vitaminE improve the cellular and humoral immune response of broiler chickens. Int. J. Poult. Sci., 5: 121127.

Al-Daraji, H. J; A. O. Tahir (2014). Effect of L-carnitine on duck breeder fertility, hatchability and sex hormones. Res. Opin. in Anim. \& Vet. Sci., 11, 608-613.

Atakisi, O; E. Atakisi and A. Kart, (2009). Effects of dietary zinc and Larginine supplementation on total antioxidants capacity, lipid peroxidation, nitric oxide, egg weight and blood biochemical values in Japanese quails. Biol. Trace Element Res., 132: 136-143.

Basiouni, G. F. (2009). The effect of feeding an extra amount of arginine to local Saudi hens on luteinizing hormone secretion. J. Biol. Sci., 9: 617-620.

Basiouni G. F; H. Najib, M. M. Zaki and A. S. Al-Ankari (2006) Influence of extra supplementation with arginine and lysine on overall performance, ovarian activities and humoral immune response in local Saudi hens. Int. J. Poult. Sci. 5:441-448.

Basiouni G. F; M. Khalid, A. A. AlHozab and W. Haresign (1999). Effect of arginine injections on gonadotrphin secretion in prepubertal Zomri goats native to Saudi Arabia. J. Agric. Sci. Mansoure Univ., 24: 6465-6474.

Biliar, T. R. (1995). Nitric oxide: Novel biology with clinical relevance. Ann. Sury., 221: 339-349.

Ciftci, H; A. Verit, M. Savas, E. Yeni and O. Erel (2009). Effects of Nacetylcysteine on semen parameters and oxidative/antioxidant status.
Urology 74: $73-76$.

Corzo, A. and M. Kidd (2003). Arginine needs of the chick and growing broiler. Int. J. Poult. Sci., 2: 379382.

Cremades, A; C. Ruzafa, F. Monserrat, A. J. López-Contreras andR. Peñafiel (2004). Influence of dietary arginine on the anabolic effects of androgens. J. of Endocr. 183: 343-351.

Das, S. C; N. Isobe, M. Nishibori, Y. Yoshimura (2006). Expression of transforming growth factorbisoforms and their receptors in utero-vaginal junction of hen oviduct in presence or absence of resident sperm with reference to sperm storage. Reprod. 132: 781790.

Duncan, D. B. (1955). Multiple range and F test. Biometric, 11: 1-42.

El-Taieb, M. A; R. Herwig, E. A. Nada, J. Greilberger and M. Marberger (2009). Oxidative stress and epididymal sperm transport, motility and morphological defects. Eur. J. Obstet Gynecol Reprod Biol. 144:199-203.

Emadi, M; F. Jahanshiri, K. Kaveh, M. H. Bejo, A. Ideris and R. A. Alimon, (2011). Nutrition and immunity: the effects of the combination of arginine and tryptophan on growth performance, serum parameters and immune response in broiler chickens challenged with infectious bursal disease vaccine. Avian Pathology 40: 63-72.

Fayh, A. P; R. Friedman, K. B. Sapata and A. R. Oliveira (2007). The L-arginine supplementation during seven days was ineffective to augment both GH and IGF-I release in individual male adults. Arq Bras Endocr. Metab., 51 587-592.

Feed composition tables for Animal \& 
Poultry feedstuffs used in Egypt (2001). Technical bulletin No. 1, central lab for feed and food; Ministry of Agric.

Guo, Y. W; B. L. Shi, S. M. Yan, Y. Q. Xu, J. L. Li and T. Y. Li (2015). Effects of arginine on cytokines and nitric oxide synthesis in broilers. J. Anim. Plant Sci. 25(2): 366-371.

Kalamah, M.A., M.M. El-Nadi, L.M. Goher, and Soliman, M.M. (2000). Some factors affecting fertility and hatchability using artificial insemination in Norfa chickens. $3^{\text {rd }}$ All Africa Conference on Animal Agric. and $11^{\text {th }}$ Conference of the Egyptian Society of Animal Production, Alex. Egypt, 6-9 November, 597-605

Khajali, F. and R.F. Wideman (2010). Dietary arginine: Metabolic, environmental, immunological and physiological interrelationships. World's Poult. Sci. J., 66: 751-766.

Khalaji, S; M. Zaghari, M. Ganjkhanloo, F. Ghaziani (2013). Arginine, soy isoflavone and hydroxypropylmethylcellulose have protective effects against obesity in broiler breeder hens fed on high-energy diets.Br. Poult. Sci., 54, 766-779.

Kim, M. H; D. S. Seo, and Y. Ko (2004). Relationship between egg productivity and Insulin-Like Growth Factor-I genotypes in Korean native Ogol chickens. Poult. Sci., 83:1203-1208.

Ko, E. Y; and E. S. Sabanegh (2014). The role of nutraceuticals in male fertility. Urologic Clinics of North America, 41: 181-193.

Le Roith, D; C. Bondy, S. Yakar, J. L. Liu, and A. Butler (2001). The somatomedin hypothesis. Endocr. Rev. 22: 53-74.

Li, H.Y., S.M. Yan, B.L. Shi, and X.Y. Guo (2009). Effect of chitosan on nitric oxide content and inducible nitric oxide synthase activity in serum and expression of inducible nitric oxide synthase mRNA in small intestine of broiler chickens. Asian-Aust. J. Anim. Sci. 22: 1048-1053.

Manwar, S. J; R. P. Moudgal, K. V. H. Sastry, J. S. Tyagi and V.K. Saxena (2003). Nitric oxide regulating immune functions in egg type Japanese quail. Ind. J. Poult.Sci., 38: 133-136.

Miller, J.F. (2004). Events that led to the discovery of T-cell development and function- a personal recollection. Tissue Antigens, 63: 509-517.

Montgomery, H. A. C. and J. F. Dymock (1961). Analyst 86: 414.

Murakami, A. E; I. M. F. Jovanir, L. Hernandes, T. C. Santos (2012). Effects of starter diet supplementation with arginine on broiler production performance and on small intestine morphometry. Pesq. Vet. Bras. Vol.32 no.3 Rio de Janeiro Mar. 2012.

Najib, H. and G. Basiouni, (2004). Determination of the nutritional requirements of the Local Saudi chickens: 1. Effect of Arginine inclusion, in excess of the leghorn requirement, on performance of the local Saudi chickens. Scientific J. of King Faisal Univ. Basic and Appl. Sci., 5: 131-144.

NRC. (1994). National Research Council, Nutrient requirements of poultry. 9 th Ed., National Academy press, Washington, D. C.

SAS institute (2001). SAS Users Guide Statistics Version $10^{\text {th }}$, 16Edition, SAS Inst., Cary, NC.

Schaefer, E. L; and J. Seidenfeld (1987). Effects of polyamine depletion on serum stimulation of quiescent $3 \mathrm{~T} 3$ 
murine fibroblast cells. J Cell Physiol.133:546-552.

Schuber, F. (1989). Influence of polyamines on membrane functions. Biochem. J.260:1-10.

Sharideh, H; L. Esmaeile Neia , M. Zaghari, M. Zhandi, A. Akhlaghi and L. Lotfi (2015). Effect of feeding guanidinoacetic acid and Larginine on the fertility rate and sperm penetration in the perivitelline layer of aged broiler breeder hens. J. of Anim. Physiol. and Anim. Nutr. 1-7.

Siddique, R. A and S. K. Atreja, (2013). Effect of 1-Arginine and spermineNONO ate on motility, viability, membrane integrity and lipid peroxidation of Murrah buffalo (Bubalus bubalis) spermatozoa. Livestock Sci., 153: 147-153.

Silva L. M. G. S; A. E. Murakami, J. I. M. Fernandes, D. Dalla Rosa, J. F. Urgnani (2012). Effects of dietary arginine supplementation on broiler breeder egg production and hatchability. Braz. J. of Poult. Sci., 14:267-273.

Soliman, M. M., El-Slamony, A. E. Hassaan, S. F. and Ragaa E. Abd El-Karim (2011). Role of sodium or aluminum salts in modulating productivity performance and some physiological traits in local chickens. 1-During growing period. Egypt. Poult. Sci., 31:855-866.

Stechmiller, J. K; B. Langkamp-Henken, B. Childress, Herrlinger-Garcia, K. A. Hudgens and J. Tian (2005). Arginine supplementation does not enhance serum nitric oxide levels in elderly nursing home residents with pressure ulcers. Biol. Res. Nursing, 6: 289-299.
Steven, S. (2000). Male infertility: Nutritional and Environmental Consideration. Alternate Medicine Revolution 5:28-38.

Takahashi,T., M. Kawashima, M. Kamiyoshi and K. Tanaka (1994). Arginine vasotocin receptor binding in the hen uterus (shell gland) before and after oviposition. Eur. J. Endocr., 130: 366-372.

Toghyani, M.; S. Tahmasebi, F. Zamani, M. Modaresi and $M$. Mohammadrezaei (2012). Effect of in Ovo feeding of arginine and threonine on growth performance and digestive organ development of broiler chicks. $24^{\text {th }} \mathrm{W}$. Poult. Congress: 44-47.

Tsai, H. J; H. F. Shang, C. L. Yeh and S. L. Yeh (2002). Effects of arginine supplementation on antioxidant enzyme activity and macrophage response in burned mice. Burns 28:258-263.

Wu G. (2009). Amino acids: metabolism, functions, and nutrition. Amino Acids 37:1-17.

Wu, L. Y.; Y. J. Fang and X. Y. Guo (2011). Dietary L-arginine supplementation beneficially regulates body fat deposition of meat-type ducks. Br. Poult. Sci., 52: 221-226.

Youssef S. F; S. A. M. Shaban and Inas, I. Ismail (2015). Effect of Larginine supplementation on productive, reproductive performance, immune response and gene expression in tow local chicken strains: 1- Egg production, reproductive performance and immune response. Egypt. Poult. Sci., 35: 573-590. 


\section{الملخص العربى المني \\ تأثير اضافة الأرجنين فى علائق دجاج المنتزة الفضي على بعض الهرمونات وعلاقة ذلك بالأداء

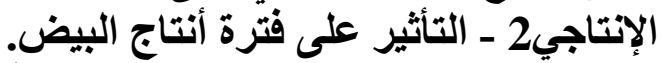

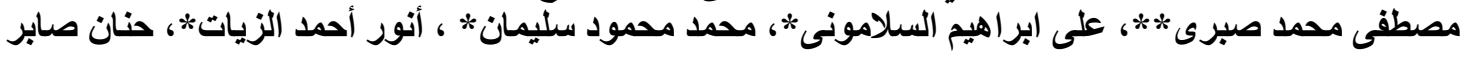 \\ محمد* محث}

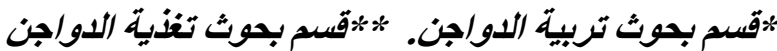

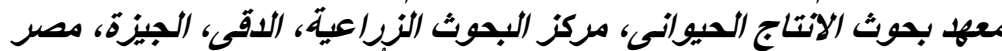

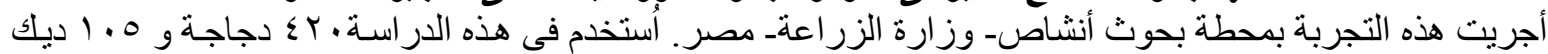

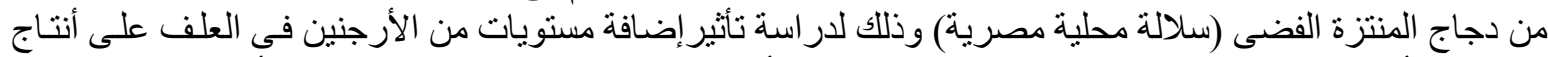

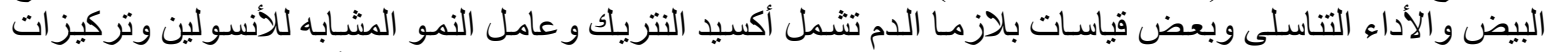

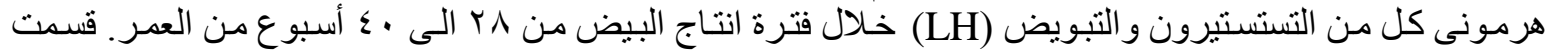

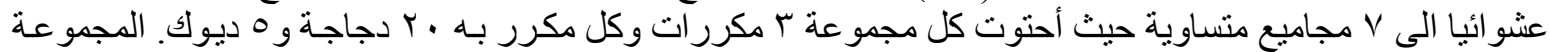

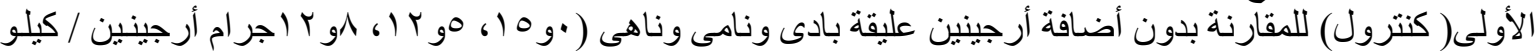

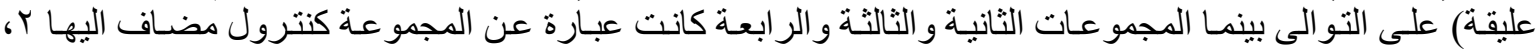

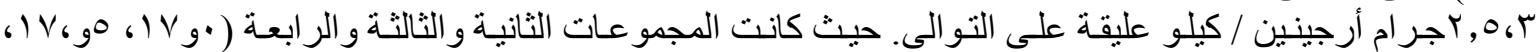

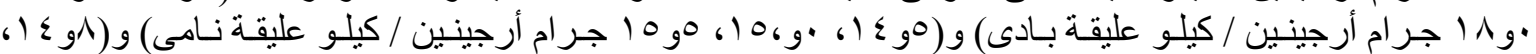

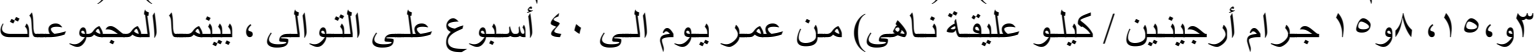

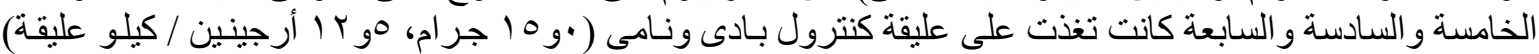

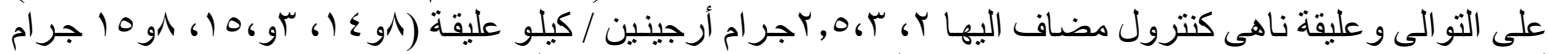

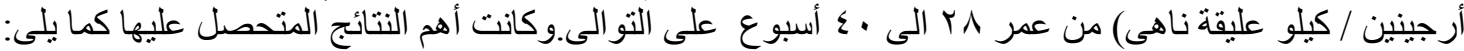

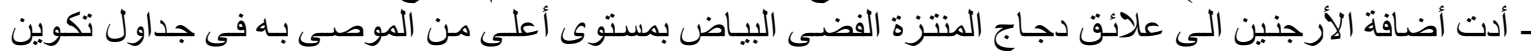

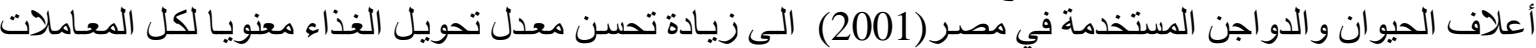

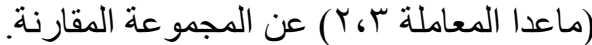

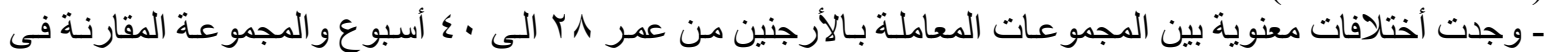

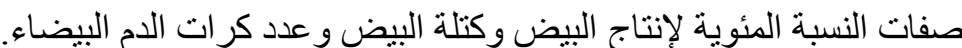

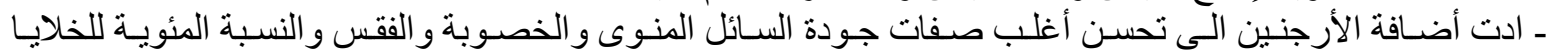

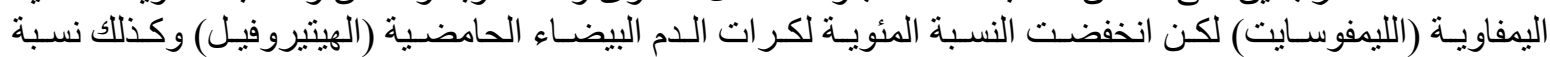

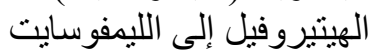

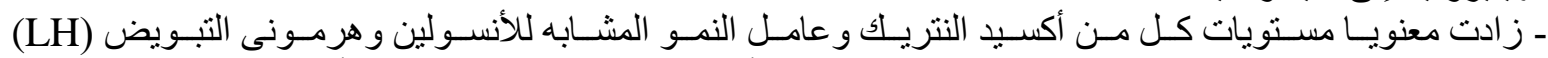

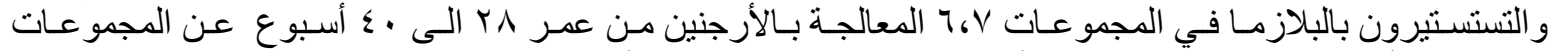

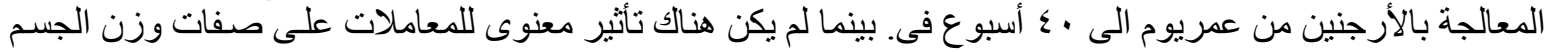

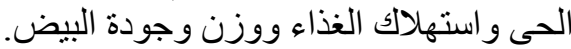

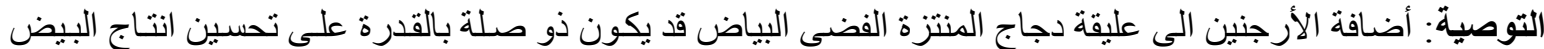

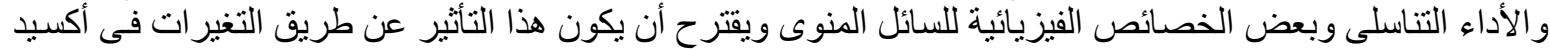
النتريك و عامل النمو المشابه للأنسولين وهرمونى التبويض (LH) و التستستيرون. 